\title{
Tropospheric aerosols over West Africa: highlights from the AMMA international program
}

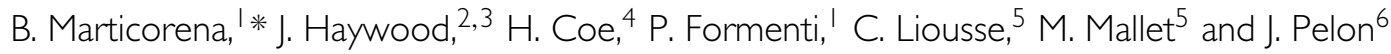 \\ 'LISA, IPSL, UMR CNRS, UPEC, UPD, France \\ ${ }^{2}$ Met Office, Exeter, UK \\ ${ }^{3}$ College of Engineering, Mathematics, and Physical Science, University of Exeter, UK \\ ${ }^{4}$ Centre For Atmospheric Science, S. E. A. E. S., University of Manchester, UK \\ ${ }^{5}$ LA, UMR CNRS, UPS, Toulouse, France \\ ${ }^{6}$ LATMOS, IPSL, UMR CNRS, UPMC, UVSQ, Paris, France
}

* Correspondence to:

B. Marticorena, LISA, IPSL, UMR

CNRS, UPEC, UPD, France.

E-mail: marticorena@lisa.u-pec.fr

Received: 3 March 2010

Revised: 13 December 2010

Accepted: 13 December 2010

\begin{abstract}
West Africa is the world's largest source of mineral dust and biomass burning aerosols. The AMMA (African Monsoon Multidisciplinary Analysis) project developed an integrated strategy combining field measurements, remote sensing and modelling studies to better quantify aerosol emissions, to extensively document their physico-chemical properties and to describe their horizontal and vertical distributions and seasonal variability. Using this information in climate and numerical weather prediction models will lead to better climate projections and better simulations of dust storms, visibility, and air quality and the impacts upon human health. Copyright (c) 2011 Royal Meteorological Society
\end{abstract}

Keywords: tropospheric aerosol; mineral dust; biomass burning aerosol; organic aerosol; radiative impact; West Africa

\section{Introduction}

The AMMA (African Monsoon Multidiscplinary Analysis) program (Polcher et al., 2011) made an integrated observational and modelling study, using ground-based and airborne and satellite measurements, to characterise the aerosol loads over continental West Africa. The programme has enabled us to describe aerosol processes from emission through atmospheric transport, to deposition or advection outside the African domain and physico-chemical properties that control their impacts, and in particular their direct radiative effect.

\section{Aerosol sources: typical spatial and seasonal patterns}

Specific inventories of carbonaceous aerosols have been developed for the 2000-2007 period over the African continent (Liousse et al., 2010). Aerosol emissions from biomass burning are estimated based on satellite observations of burned areas and type of combustion (Liousse et al., 2010). In the northern hemisphere, they are maximum in December and mainly located in Central Africa, with a few hot spots in Western Africa and a year-to-year variability as high as $50 \%$. Regional inventories of anthropogenic emissions due to fossil fuel and biofuel (gasoline, diesel, wood, crop residues, etc.) consumption, includes regional specificities, such as traffic from two-wheel vehicles (Assamoi and Liousse, 2010).
These inventories highlight the local contribution of large African cities (e.g. Lagos, Cotonou), in agreement with observations (Reeves et al., 2010). Regional and global simulations using these new inventories better agree with observations (Liousse et al., 2010; Tummon et al., 2010). The anthropogenic emissions (fuel/biofuel/traffic/industry) of carboneaceous aerosols are comparable to those from open biomass burning, with emission scenarios suggesting a likely future increase.

Mineral dust was ubiquitously found in the troposphere over West Africa all along the year. However, a typical seasonal dust cycle is observed with maximum surface concentrations in winter due to Saharan dust transport, although extremely high daily concentrations $\left(>4000 \mu \mathrm{g} \mathrm{m}^{-3}\right)$ are recorded during both dry and wet seasons (Marticorena et al., 2010). In the rainy season, these pulses of high dust concentrations are due to local emissions by Mesoscale Convective Systems (MCSs) (Marticorena et al., 2010). These MCSs also bring precipitation to the Sahel and wet deposition acts extremely efficiently remove dust from atmosphere (Flamant et al., 2008). The Sahel is therefore a region of Saharan dust deposition during the dry season (Rajot et al., 2008), but also an intense source of local dust emission at the beginning of the wet season. Several severe dust events (Flamant et al., 2007; Slingo et al2008) provide welldocumented case studies for testing and improving mesoscale dust models (Menut et al., 2008; Tulet et al., 2008). 


\section{Chemical and physical properties and processing}

Physico-chemical properties of mineral dust, and in particular those controlling their radiative effect, have been extensively investigated. For the first time, size-resolved mineral dust emission fluxes have been measured in situ, confirming the change in the emitted dust size-distribution with dynamical conditions (Sow et al., 2009). Significantly different size distributions are recorded between locally produced and advected dust (Rajot et al., 2008). While the non-sphericity of mineral dust particles has been clearly stated, their aspect ratio (1.7) was found almost constant on the whole size-spectrum (Chou et al., 2008). Regional signatures in iron oxides have been distinguished according to dust origin (Formenti et al., 2008). Despite their low contribution to the dust mass $(2.4-4.5 \%$, i.e. $46 \%$ and $59 \%$ of total iron), iron oxides strongly influence dust absorption characteristics (McConnell et al., 2010) and may thus impact the sign of the dust direct radiative effect.

Evidence of internal mixing of mineral dust with biomass burning particles were given during the dry season (Hand et al., 2010). Dust chemical properties are also modified during the wet season by their incorporation into cloud droplets, becoming internally mixed with sulphate, chloride and nitrate (Crumeyrolle et al., 2009; Matsuki et al., 2010). Mineral dust radiative and $\mathrm{CCN}$ properties may thus be significantly impacted by interactions with biomass burning aerosols in the dry season and with soluble organic and inorganic components brought by the monsoon flow in the wet season.

During the dry season, biomass burning is the overwhelming source of submicron organic aerosol, with size evolving by coagulation from $0.08 \mu \mathrm{m}$ close to the sources, to $0.1-0.2 \mu \mathrm{m}$ for aged biomass burning aerosol (Johnson et al., 2008; Capes et al., 2009). A constant ratio between organic mass and carbon monoxide has been observed in biomass burning plumes, close to and far downwind fire sources, while the oxygen to carbon ratio increases. This implies a loss of carbon within the plume, as highlighted in some, though not all, field and chamber studies (Grieshop et al., 2009). During the wet season, secondary organic material formed from oxidation of biogenic precursors dominates the submicron organic mass (Capes et al., 2009). The observed organic mass is grossly underestimated by the production yields derived from simulation chamber studies (Capes et al., 2009). This highlights very large gaps in our understanding of the evolution of organic aerosol in West Africa.

\section{Aerosol spatial distribution over West Africa}

The spatial redistribution of aerosols in the atmosphere is linked to large-scale dynamical patterns. Field observations from AMMA show that various small scale and mesoscale processes are also involved in the generation of mineral dust, aerosol mixing in the boundary layer, and vertical transport to upper atmospheric layers.

During the dry season, two main anticyclonic regions are located close to the Azores and Saint Helena islands, with low pressure over central Africa linked to large-scale heating. The InterTropical Convergence Zone (ITCZ) is located slightly north of the Equator and a reduced monsoon inflow prevails south of the Sahel. The so-called 'Harmattan Front' separates the dusty air to the north from the biomass burning laden air to the south although significant mixing occurs at the boundary (Haywood et al., 2008). The stronger heating to the South causes the relatively unstable, moist, warm and biomass burning laden air to be undercut by drier cooler dust-laden air. This leads to a two-layer structure: the lower (elevated) layer being dominated by dust (biomass burning aerosol). Ground-based and airborne (Cloud-Aerosol Lidar and Infrared Pathfinder Satellite Observations, CALIPSO) lidar systems offered the unique capability to monitor aerosol vertical distribution, and demonstrates the persistency of this two-layer structure at the regional and multi-annual scale (Léon et al., 2009; Cavalieri et al., 2010).

In the summer, the energy budget of the system is modified. A strong heat low develops over Sahara, reinforcing the pressure gradient with the Gulf of Guinea. The ITCZ moves north, and the monsoon inflow reaches the North Sahel (Lafore et al., 2011). Meanwhile, the anticyclone in the southern hemisphere extends over land and into central Africa. These dynamical patterns and the development of boundary layer height over northern Africa by solar heating (Milton et al., 2008) favour dust transport over the Atlantic and the Caribbean Sea by the trade winds in the Saharan Air Layer (SAL). The vertical structure of this dust-laden SAL has been documented from the central Sahara (Cuesta et al., 2009) to the Atlantic coast, where the maximum summer aerosol optical depth (AOD) is associated with a maximum in the SAL elevation (up to $6 \mathrm{~km}$ ) (Léon et al., 2009).

The systematic formation of nocturnal gusts, evidenced locally by several lidar observations (Haywood et al., 2008) and from satellite (MODIS Deep Blue; SEVIRI/MSG) is one of the possible processes leading to increased dust content in the lower Saharan boundary layer. During summer, 'density currents' linked to convective clouds are responsible for additional dust emissions in the Sahara (Marsham et al., 2008). It has also been shown that the dynamics of the Intertropical frontal disturbance cause significant dust vertical transport from the boundary layer aloft, both in the winter season for the biomass particles (Pelon et al., 2008) and for dust in the summer season (Boukaram et al., 2008). 


\section{Aerosol optical properties and radiative impact}

The single scattering albebo (SSA), i.e. the ratio of scattering to total light extinction (absorption plus scattering) is a critical parameter to determine the sign of the aerosol forcing. SSA and local direct radiative forcing were estimated at several locations of West Africa with different aerosol conditions.

Independent estimates consistently show that mineral dust is mainly scattering radiation in the visible range. The SSA of the submicron dust has been estimated to be $\sim 0.99 \pm 0.01$ (at $0.55 \mu \mathrm{m}$ ) (Osborne et al., 2008), and $\sim 0.90$ with the addition of the coarse mode (McConnell et al., 2008). The dust SSA is lower in the summer than in the winter, possibly due to sources with different mineralogies. This range of SSA is consistent with previous estimations from the literature derived from ground-based, aircraft or satellite measurements in this region. The optical properties of biomass burning aerosol exhibit a much higher variability, likely due to different ages, sources, and combustion characteristics. From airborne observations, SSA of biomass burning aerosol over West Africa is 0.81 on average (Johnson et al., 2008), i.e. comparable to estimates in Brazilian fires but significantly more absorbing than South African or boreal fires. Regions affected both by mineral dust and biomass burning particles display a large variability in the SSA $(0.81-0.98$ at $0.52 \mu \mathrm{m}$, i.e. Mallet et al., 2008) depending on the relative contributions of each aerosol, the lower (higher) value representing higher contributions from biomass burning (mineral dust).

During the dry season 2006 in Niamey, the mineral dust surface layer and the upper biomass burning aerosol layer contributed almost equally to a daytime solar direct radiative effect at the surface, $\Delta F_{\mathrm{SURF}}$, estimated at $-56 \mathrm{~W} \mathrm{~m}^{-2}$ (Haywood et al., 2008; Milton et al., 2008). At the same period, in Djougou, the daily average $\Delta F_{\text {SURF }}$ was estimated to be $-45 \mathrm{~W} \mathrm{~m}^{-2}$ (Mallet et al., 2008). The daily forcing efficiency at the surface $\left(\Delta F_{\text {SURF }} / A O D\right)$ has been estimated as $-31 \mathrm{~W} \mathrm{~m}^{-2} \mathrm{AOD}^{-1}$ for heavy dust events and $-62 \mathrm{~W} \mathrm{~m}^{-2} \mathrm{AOD}^{-1}$ for mixtures of biomass burning and dust aerosol (Derimian et al., 2008). $F_{\text {SURF }}$ is strongly influenced by the total AOD, while the radiative effect at the top of the atmosphere, $F_{\text {TOA }}$, is mainly controlled by the relative proportions of dust and biomass burning aerosols and the surface reflectance (Raut and Chazette, 2008). But the dusty layer possibly enhances the absorption of the upper biomass burning layer. These results underline the large direct radiative effect of mineral dust and biomass burning layers and highlight the importance of aerosol layering on this forcing. Finally, the solar atmospheric forcing (i.e. the amount of energy absorbed by the atmospheric layer), $\Delta F_{\mathrm{ATM}}$, is higher for biomass burning aerosols than for mineral dust. But a significant terrestrial $\Delta F_{\mathrm{ATM}}$ is caused by absorption and re-emission of terrestrial radiation by mineral dust (Mallet et al., 2009).

\section{Conclusion and perspectives}

The AMMA project has provided valuable insights into the emissions, deposition and mixing processes of mineral dust, biomass burning, and biogenic aerosol over West Africa and a broad picture of their distribution, properties and radiative effects. This information is currently being ingested in climate and numerical weather prediction models to better describe their spatial and temporal variability and to asses their impacts. These results highlight the need to account for the absorption properties and vertical distribution of the different aerosols to properly estimate their radiative forcing. The intensity of this forcing implies a strong interaction with the local and regional dynamics. As an example, mineral dust was found to significantly impact on the vertical structure of the atmosphere (Tulet et al., 2008) and on the simulation of convective activity in meteorological forecast models (Chaboureau et al., 2006). The AMMA program has initiated work at ECMWF and Hadley Centre to include aerosols in their forecasting models (Milton et al., 2008). This will lead to better climate projections and better simulations of dust storms and visibility. Serious issues on air quality and human health have also been raised such as the impact of air pollution in African cities and the possible links between mineral dust and meningitis epidemics in the Sahel.

\section{Acknowledgements}

The support of the AMMA project is gratefully acknowledged (see http://onlinelibrary.wiley.com/doi/10.1002/asl.331/full for full acknowledgement).

\section{References}

Assamoi E, Liousse C. 2010. Focus on the impact of two wheel vehicles on African combustion aerosols emissions. Atmospheric Environment 44: 3985-3996.

Bou Karam D, Flamant C, Knippertz P, Reitebuch O, Pelon J, Chong M, Dabas A. 2008. Dust emissions over the Sahel associated with the West African monsoon intertropical discontinuity region: a representative case-study. Quaterly Journal of Royal Meteorological Society 134: 621-634.

Capes G, Murphy JG, Reeves CE, McQuaid JB, Hamilton JF, Hopkins JR, Crosier J, Williams PI, Coe H. 2009. Secondary organic aerosol from biogenic VOCs over West Africa during AMMA. Atmospheric Chemistry and Physics Discussion 9: 2533-2558.

Cavalieri O, Di Donfrancesco G, Cairo F, Fierli F, Snels M, Viterbini M, Cardillo F, Chatenet B, Formenti P, Marticorena B, Rajot JL. 2011. The AMMA mulid network for aerosol characterization in West Africa. International Journal of Remote Sensing (in press).

Chaboureau J-P, Tulet P, Mari C. 2006. Diurnal cycle of dust and cirrus overWest Africa as seen from Meteosat Second Generation satellite and a regional forecast model. Geophysical Research Letter DOI: 10.1029/2006GL027771.

Chou C, Formenti P, Maille M, Ausset P, Helas G, Osborne S, Harrison M. 2008. Size distribution, shape and composition of dust 
aerosols collected during the AMMA SOP0 field campaign in the northeast of Niger, January 2006. Journal of Geophysical Research 113: D00C10, DOI: 10.1029/2008JD009897.

Crumeyrolle S, Gomes L, Tulet P, Matsuki A, Schwarzenboeck A, Crahan K. 2008. Increase of the aerosol hygroscopicity by aqueous mixing in a mesoscale convective system: a case study from the AMMA campaign. Atmospheric Chemistry and Physics Discussion 8: $10057-10103$.

Cuesta J, Marsham JH, Parker DJ, Flamant C. 2009. Dynamical mechanisms controlling the vertical redistribution of dust and the thermodynamic structure of the West Saharan atmospheric boundary layer during summer. Atmospheric Science Letters 10: 34-42, DOI 10.1002/asl.207.

Derimian Y, Léon J-F, Dubovik O, Chiapello I, Tanré D, Sinyuk A, Auriol F, Podvin T, Brogniez G, Holben BN. 2008. Radiative properties of aerosol mixture observed during the dry season 2006 over M'Bour, Senegal (African Monsoon Multidisciplinary Analysis campaign). Journal of Geophysical Research 113: D00C09, DOI: 10.1029/2008JD009904.

Flamant C, Lavaysse C, Todd MC, Chaboureau J-P, Pelon J. 2009. Multi-platform observations of a representative springtime case of Bodélé and Sudan dust emission, transport and scavenging over West Africa. Quaterly Journal of Royal Meteorological Society 135(639): $413-430$.

Formenti P, Rajot JL, Desboeufs K, Caquineau S, Chevaillier S, Nava S, Gaudichet A, Journet E, Triquet S, Alfaro S, Chiari M, Haywood J, Coe H, Highwood E. 2008. Regional variability of the composition of mineral dust from western Africa: Results from the AMMA SOP0/DABEX and DODO field campaigns. Journal of Geophysical Research 113: D00C13, DOI: 10.1029/2008JD009903.

Grieshop AP, Donahue NM, Robinson AL. Laboratory investigation of photochemical oxidation of organic aerosol from wood fires 2: analysis of aerosol mass spectrometer data. 2009. Atmospheric Chemistry and Physics 9(6): 2227-2240.

Hand V, Capes G, Vaughan D, Formenti P, Haywood JM, Coe H. 2010. Evidence of internal mixing of African dust and biomass burning particles by individual particle analysis using electron beam techniques. Journal of Geophysical Research 115: D13301, DOI: 10.1029/2009JD012938.

Haywood JM, Pelon J, Formenti P, Bharmal N, Brooks M, Capes G, Chazette P, Chou C, Christopher S, Coe H, Cuesta J, Derimian Y, Desboeufs K, Greed G, Harrison M, Heese B, Highwood EJ, Johnson B, Mallet M, Marticorena B, Marsham J, Milton S, Myhre G, Osborne S, Parker DJ, Rajot J-L, Schulz M, Slingo A, Tanré D, Tulet P. 2008. Overview of the dust and biomass burning experiment and african monsoon multidisciplinary analysis special observing period-0. Journal of Geophysical Research 113: D00C17, DOI: 10.1029/2008JD010077.

Johnson BT, Osborne SR, Haywood JM, Harrison MAJ. 2008. Aircraft measurements of biomass burning aerosols over West Africa during DABEX. Journal of Geophysical Research 113: D00C06, DOI: $10.1029 / 2007 J D 009451$.

Lafore J-P, Flamant C, Guichard F, Parker DJ, Bouniol D, Fink AH, Giraud V, Gosset M, Hall N, Höller H, Jones SC, Protat A, Roca R, Roux F, Saïd F, Thorncroft C. 2011. Progress in understanding of weather systems in West Africa. Atmospheric Science Letters 12: 7-12, DOI: 10.1002/asl.335

Léon J-F, Derimian Y, Chiapello I, Tanré D, Podvin T, Chatenet B, Diallo A, Deroo C. 2009. Aerosol vertical distribution and optical properties over M'Bour $\left(16.96^{\circ} \mathrm{W} ; 14.39^{\circ} \mathrm{N}\right)$, Senegal from 2006 to 2008. Atmospheric Chemistry and Physics Discussion 9 $16295-16330$.

Liousse B, Guillaume JM, Grégoire M, Mallet C, Galy V, Pont A, Akpo M, Bedou P, Castéra L, Dungall E, Gardrat C, Granier A, Konaré F, Malavelle A, Mariscal A, Mieville R, Rosset D, Serça F, Solmon F, Tummon E, Assamoi V, Yoboué P, Van Velthoven. 2010. Updated African biomass burning emission inventories in the framework of the AMMA-IDAF program, with an evaluation of combustion aerosols. Atmospheric Chemistry and Physics 10: 7347-7382.

Mallet M, Tulet P, Serça D, Solmon F, Dubovik O, Pelon J, Pont V, Thouron O. 2009. Impact of dust aerosols on the radiative budget, surface heat fluxes, heating rate profiles and convective activity over West Africa during March 2006. Atmospheric Chemistry and Physics Discussion 9: 2967-3006.

Mallet M, Pont V, Liousse C, Gomes L, Pelon J, Osborne S, Haywood J, Roger JC, Dubuisson P, Mariscal A, Thouret V, Goloub P. 2008. Aerosol direct radiative forcing on Djougou (northern Benin) during the African monsoon multidisciplinary analysis dry season experiment (SOP-0). Journal of Geophysical Research 113: D00C01, DOI: 10.1029/2007JD009419.

Marsham JH, Parker DJ, Grams CM, Taylor CM, Haywood JM. Uplift of Saharan dust south of the intertropical discontinuity. Journal of Geophysical Research 113: D21102, DOI:10.1029/2008JD009844.

Marticorena B, Chatenet B, Rajot JL, Traoré S, Coulibaly MM, Diallo A, Koné II, Maman A, NDiaye T, Zakou AA. 2010. Temporal variability of mineral dust content over West Africa: analyses of a pluriannual monitoring from the AMMA Sahelian Dust Transect. Atmospheric Chemistry and Physics 10: 8899-8915.

Matsuki A, Schwarzenboeck A, Venzac H, Laj P, Crumeyrolle S, Gomes L. 2009. Effect of surface reaction on the cloud nucleating properties of mineral dust: AMMA aircraft campaign in summer 2006. Atmospheric Chemistry and Physics Discussion 9: 1797-1830.

McConnell CL, Highwood EJ, Coe H, Formenti P, Anderson B, Osborne S, Nava S, Desboeufs K, Chen G, Harrison MAJ. Seasonal variations of the physical and optical characteristics of Saharan dust: results from the Dust Outflow and Deposition to the Ocean (DODO) experiment. 2008. Journal of Geophysical Research 113: D14S05, DOI:10.1029/2007JD009606.

Menut L, Chiapello I, Moulin C. 2009. Predictability of mineral dust concentrations: the African Monsoon multidisciplinary analysis first short observation period forecasted with CHIMEREDUST. Journal of Geophysical Research 114: D07202, DOI: 10.1029/2008JD010523.

Milton SF, Greed G, Brooks M, Haywood JM, Johnson B, Allan RP, Slingo A, Grey WMF. 2008. Modeled and observed atmospheric radiation balance during the West African dry season: role of mineral dust, biomass burning aerosol, and surface albedo. Journal of Geophysical Research 113: D00C02, DOI:10.1029/2007JD009741.

Osborne SR, Johnson BT, Haywood JM, Baran AJ, Harrison MAJ, McConnell CL. 2008. Physical and optical properties of mineral dust aerosol during the Dust and Biomass-burning Experiment. Journal of Geophysical Research 113: D00C03, DOI:10.1029/2007JD009551.

Pelon J, Mallet M, Mariscal A, Goloub P, Tanré D, Bou Karam D, Flamant C, Haywood JM, Pospichal B, Victori S. 2008. Microlidar observations of biomass burning aerosol over Djougou (Benin) during African Monsoon Multidisciplinary Analysis. Journal of Geophysical Research 113: D00C18, DOI: 10.1029/2008JD009976.

Polcher J, Parker DJ, Gaye A, Diedhiou A, Eymard L, Fierli F, Genesio L, Hoeller H, Janicot S, Lafore J-P, Karambiri H, Lebel T, Redelsperger J-L, Reeves CE, Ruti P, Sandholt I, Thorncroft C. 2011. AMMA's contribution to the evolution of prediction and decision-making systems for West Africa. Atmospheric Science Letters 12: 2-6, DOI: 10.1002/asl.320.

Rajot JL, Formenti P, Alfaro S, Desboeufs K, Chevaillier S, Chatenet B, Gaudichet A, Journet E, Marticorena B, Triquet S, Maman A, Mouget N, Zakou A. 2008. AMMA dust experiment: An overview of measurements during the dry season special observation period (SOP0) at the Banizoumbou (Niger) supersite. Journal of Geophysical Research 113: D00C14, DOI: 10.1029/2008JD009906.

Raut J-C, Chazette P. 2008. Radiative budget in the presence of multilayered aerosol structures in the framework of AMMA SOP-0. Atmospheric Chemistry and Physics 8: 6839-6864.

Reeves CE, Formenti P, Afif C, Ancellet G, Attie J-L, Bechara J, Borbon A, Cairo F, Coe H, Crumeyrolle S, Fierli F, Flamant C, Gomes L, Hamburger T, Lambert C, Law KS, Mari C, Matsuki A, Methven J, Mills GP, Minikin A, Murphy JG, Nielsen JK, Oram DE, Parker DJ, Richter A, Schlager H, Schwarzenboeck A, Thouret V. 2010. Chemical and aerosol characterisation of the troposphere over West Africa during the monsoon period as part of AMMA, chemical and aerosol characterisation of the troposphere over West Africa during the monsoon period as part of AMMA. Atmospheric Chemistry and Physics Discussion 10: 7575-7601. 
Slingo A, Ackerman TP, Allan RP, Kassianov EI, McFarlane SA, Robinson GJ, Barnard JC, Miller MA, Harries JE, Russell JE, Dewitte S. 2006. Observations of the impact of a major Saharan dust storm on the atmospheric radiation balance. GRL 33: L24817, DOI: $10.1029 / 2006$ GL027869.

Sow M, Alfaro SC, Rajot JL, Marticorena B. 2009. Size resolved dust emission fluxes measured in Niger during 3 dust storms of the AMMA experiment. Atmospheric Chemistry and Physics 9: 3881-3891.
Tulet P, Mallet M, Pont V, Pelon J, Boone A. 2008. The 7-13 March 2006 dust storm over West Africa: generation, transport, and vertical stratification. Journal of Geophysical Research 113: DOI: 10.1029/2008JD009871.

Tummon F, Solmon F, Liousse C, Tadross M. 2010. Simulation of the climatic impacts of the natural aerosol loading over southern Africa during the biomass burning season using RegCM3. Journal of Geophysical Research 115: D19206, DOI: 10.1029/2009JD 013738. 